\title{
14- vs. 42-Paddock Rotational Grazing: Aboveground Bio- mass Dynamics, Forage Production, and Harvest Efficiency
}

\author{
R.K. HEITSCHMIDT, S.L. DOWHOWER, AND J.W. WALKER
}

\begin{abstract}
Research was initiated at the Texas Experimental Ranch in 1981 to quantify the effects of 2 stocking densities, equivalent to 14- and 42-paddock rotational grazing (RG) treatments, on aboveground biomass dynamics, aboveground net primary production (ANPP), and harvest efficiency of forage. Baseline data were collected in 1981 from 3 adjacent 30-ha paddocks in a 14-paddock, cell designed RG treatment. Near the beginning of the 1982 growing season the center paddock was subdivided into three, 10-ha paddocks to establish the RG-42 treatment. Stocking densities in the 14- and 42-paddock treatments were 4.2 and $12.5 \mathrm{AU} /$ ha, respectively, from March 1982 to June 1984 and 3.0 and 9.1 AU/ha from June to November 1984. During 1981, estimated ANPP in the two RG-14 paddocks averaged $4,088 \mathrm{~kg} / \mathrm{ha}$ as compared to 5,762 in the single RG-42 paddock. Following subdivision, ANPP in the RG14 paddocks averaged $2,533 \mathrm{~kg} / \mathrm{ha}$ as compared to $2,670 \mathrm{~kg} / \mathrm{ha}$ in the RG-42 paddocks. Although ANPP varied significantly among the 4 years of the study it was not affected by density treatment. Likewise, harvest efficiency varied among years but was unaffected by density treatment. A verage harvest efficiency over the 4 years was about $42 \%$. Aboveground biomass dynamics were also generally unaffected by density treatments.
\end{abstract}

Key Words: stocking density, cell grazing, aboveground net primary production, growth dynamics

Interest in rotational-type grazing systems (RG) has increased dramatically in the U.S. during the past 10 years. Of particular interest has been the claim that proper implementation of a multipaddock RG system will improve rangeland productivity in terms of livestock carrying capacity (Savory and Parsons 1980). This

\footnotetext{
Authors are associate professor, research associate, and former research associate, Texas Agr. Exp. Sta., Box 1658 , Vernon 76384.

Appreciation is expressed to the Swen R. Swenson Cattle Co. for providing the land, livestock, and facilities for this study and the Texas Experimental Ranch Committee for providing financial assistance. Appreciation is expressed to Dr. Trey Richardson, Institute of Statistics, Texas A\&M University, College Station, for his assistance in data summarization and statistical analyses.

Report is published with approval of the Director, Texas Agr. Exp. Sta. as TA 21649.

Manuscript accepted 30 October 1986.
}

increase in carrying capacity has been attributed generally to substantial increases in forage production as a result of the positive effects of the physical impact of the grazing herd on plant growth and ecological succession. An extension of this claim has been that as livestock density is increased a similar increase in herbage production can be anticipated because of the greater amount of animal impact (herd effect). This claim was made, however, in the absence of any supportive scientific data. Thus, in 1981 we designed a series of studies to evaluate the effects of a RG treatment on quantity and quality of herbage produced and consumed, harvest efficiency, animal behavior, watershed condition, livestock performance (cow/calf), and economic profits. This paper is the third of a series of papers that report on the effects of 2 livestock densities in a RG treatment on quantity and quality of forage produced and consumed, harvest efficiency, watershed condition (Pluhar et al. 1987), and animal behavior (Walker and Heitschmidt 1986). Our objective in this paper is to quantify the effects of a 3-fold increase in stocking density in the RG treatment on aboveground biomass dynamics, forage production, and harvest efficiency. Subsequent papers will contrast the response of the various parameters in the RG treatment to those in a yearlong continuously grazed treatment.

\section{Methods}

\section{Study Area}

Study was conducted at the Texas Experimental Ranch located $\left(99^{\circ} 14^{\prime} \mathrm{W}, 33^{\circ} 20^{\prime} \mathrm{N}\right)$ on the eastern edge of the Rolling Plains resource region. Climate is continental, semiarid, and highly variable. Annual precipitation is bimodally distributed (Fig. 1) and has averaged $682 \mathrm{~mm}$ over the past 25 years. Peak precipitation months are May $(96 \mathrm{~mm})$ and September $(118 \mathrm{~mm})$. Average maximum daily temperatures range from $11.4^{\circ} \mathrm{C}$ in January to $35.8^{\circ} \mathrm{C}$ in July. Average minimum daily temperatures range from $-2.4^{\circ} \mathrm{C}$ in January to $22.0^{\circ} \mathrm{C}$ in July.

Soils at the ranch range from deep, well-drained clays and clay loams on the rolling upland (1-3\% slopes) and in the broad valleys $(<1 \%$ slope) to shallow, stoney clay and clay loams on the steeper 


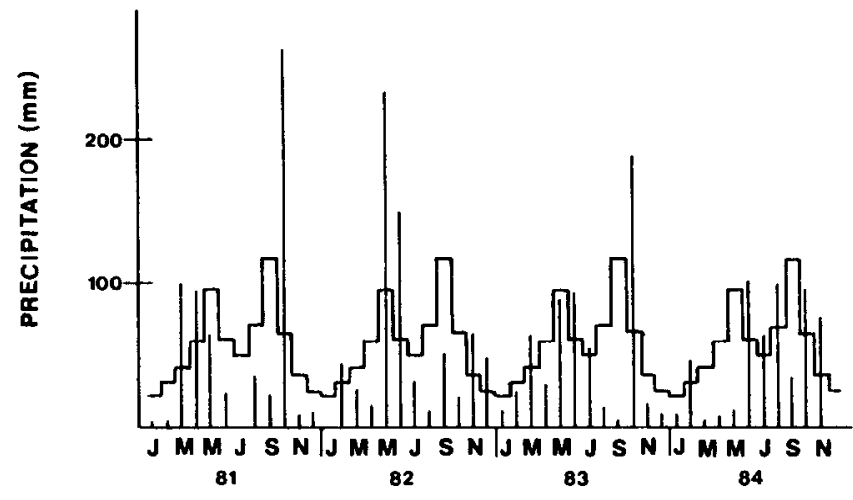

Fig. 1. Monthly precipitation ( $\mathrm{mm}$ ) at the Texas Experimental Ranch for 1981 through 1984. Closed lines represent long-term monthly averages from 1960 through 1982 (Heitschmidt et al. 1985).

slopes $(>5 \%)$. Elevation ranges from 408 to $463 \mathrm{~m}$. Vegetation is a mixture of mid-and shortgrasses with a light to moderate stand of honey mesquite (Prosopsis glandulosa var. glandulosa Torr.). Dominant midgrasses are sideoats grama [Bouteloua curtipendula (Michx.) Torr.], a warm-season perennial, Texas wintergrass (Stipa leucotricha Trin. and Rupr.) a cool-season perennial, and Japanese brome (Bromus japonicus Thunb.), a cool-season annual. The dominant shortgrass is buffalograss [Buchloe dactyloides (Nutt.) Engelm.], a warm-season perennial. Brownspine pricklypear (Opuntia phaecantha Engelm. and Bigel.) is the dominant succulent. Texas broomweed [Xanthocephalum texanum (DC.) Shinners] is the dominant annual forb and heath aster (Aster ericoides L.) is the dominant perennial forb. For a complete description of the climate, soils, and vegetation at the ranch see Heitschmidt et al. (1985).

\section{Treatment and Sample Plots}

The 465-ha, cell-designed (paddocks fenced radially around common center, see Fig. 2) RG treatment was initiated in March

\section{EXPERIMENTAL DESIGN}
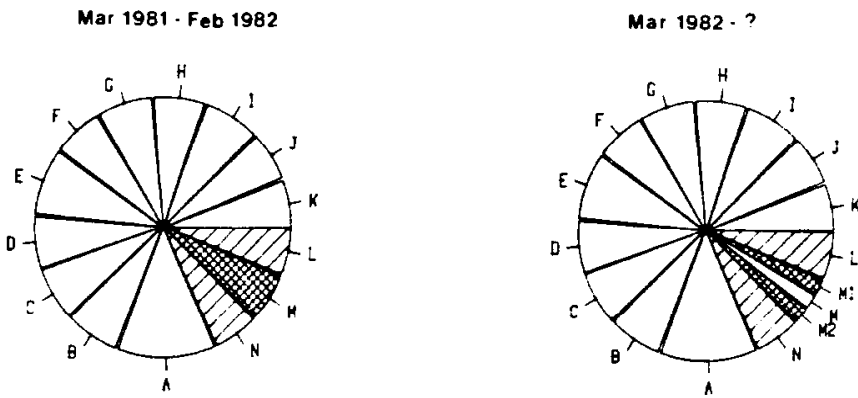

Fig. 2. Illustration depicting experimental design utilized in study. RG-14 study plots were located in paddocks $L$ and $N$. RG-42 study plots were located in paddock $M$ (1981) and paddocks $M 1$ and $M 2$ (1982-1984).

1981. Initially the treatment consisted of 14 paddocks that averaged $33 \mathrm{ha}$ in size and ranged from about 49 to 26 ha. The treatment was stocked with 125 Hereford/Angus crossbred cows at a heavy ratc of $3.7 \mathrm{ha} / \mathrm{cow} / \mathrm{yr}$. Rate of stocking was constant until June 1984 when it was reduced to $5.2 \mathrm{ha} / \mathrm{cow} / \mathrm{yr}$ because of drought. Rate of rotation was flexible and varied according to vegetation growth rates and the nutritional requirements of the cows with rates of rotation most rapid during periods of rapid vegetation growth and high nutrient requirements. Days of rest between grazing events ranged from about 30 to 65 .
Four permanent 0.25 -ha study areas were located in 3 adjacent paddocks (L, M, and N) in March 1981 (Fig. 2). Two plots were located in paddock $M$ and 1 each in paddocks $L$ and $N$. Location of the 2 study areas in the $M$ paddock was such that when the paddock was subdivided into three, 10-ha paddocks in March 1982, the 2 study areas were then located in different paddocks (M1 and M2). All study areas were located approximately two-thirds of the distance away from the center to the back of the paddocks within $400 \mathrm{~m}$ of one another. Based on desired rest periods, length of graze in the 4 paddocks ranged from 18 hours in the 10-ha paddocks to 4 days in the 27 -ha paddocks. The 10-ha paddocks hereafter are referred to as the RG-42 treatment and the 27-ha paddocks as the RG-14 treatment. 1

All 4 study areas were located on a nearly level upland site on Nuvalde soils. This soil series is a member of the fine-silty, mixed, thermic family of Typic Calciustolls. It is a deep, well-drained, moderately permeable soil of clay loam texture. Range site classification is clay loam. Dominant herbaceous species were sideoats grama, Texas wintergrass, Japanese brome, and annual broomweed. Other common grasses were buffalograss, common curlymesquite [Hilaria belangeri (Steud.) Nash], red threeawn (Aristida longiseta Steud.), silver bluestem [Bothriochloa saccaroides Swartz) Rydb.], and tumblegrass [Schedonnardus paniculatus (Nutt.) Trel.]. The areas supported a light stand of honey mesquite $(<10 \%$ canopy cover) and a sparse stand of brownspine pricklypear.

\section{Vegetation Sampling}

Immediately before and after every grazing period from March 1981 to December 1984, the herbaceous standing crop in ten, $0.25-\mathrm{m}^{2}$ quadrats was clipped at ground level. Before grazing, all 20 quadrats were located as 10 pairs. The first 10 quadrats were located randomly. The second 10 quadrats were then located near the first 10 in a paired manner with similar standing crop and composition. A coin flip identified which quadrat of the pair was clipped before grazing and which was clipped after grazing.

Herbage was clipped by the dominant species/species groups on all sample dates except during the winter of 1981 when cold, wet conditions restricted field sampling. Dominant species/species groups, hereafter referred to as species, and their designated codes were sideoats grama (Bocu), Texas wintergrass (Stle), annual grasses (Angr), other warm-season grasses (Wsgr), annual broomweeds (Xasp), and other forbs (Forb). Following drying $\left(60^{\circ} \mathrm{C}\right)$ and weighing, live/dead ratios were estimated by hand separation of 5 subsamples of each species from each study area both prior to and after grazing. Subsamples by treatment (RG-14 and RG-42), category (live and dead), and time (before and after) were then ashed at $600^{\circ} \mathrm{C}$ for expression on an organic matter basis. The same procedures were followed during the winter of 1981 except all grasses were clipped as a group. Species composition and live/dead ratios were then estimated in the laboratory by hand separation of subsamples.

Following harvest, ground litter in all quadrats was collected by hand and vacuum, floated in water to remove soil contamination, oven dried, and weighed. Subsamples were then ashed for expression on an organic matter basis.

\section{Data Summarization and Statistical Analyses}

Standing live in each quadrat was estimated by multiplying total standing crop by the percentage live estimate. Standing dead was then estimated by subtraction. Aboveground net primary production (ANPP) was calculated for each species group by summing incremental increases in either the standing live component only

\footnotetext{
Stocking rate is the integrated product of stocking density and length of grazing period. Therefore, stocking rate in any given paddock in a set-stocked RG treatment can be adjusted by changing length of grazing period. But because the objective of this study was to evaluate the effect of number of paddocks (stock density) in a $R G$ treatment on various vegetation parameters and not the effects of stocking rate, length of each grazing period was adjusted by an amount proportional to the size of treatment (RG-14 vs. RG-42) paddocks. For a more thorough discussion of the relationship between stocking rate and stocking density, see Scarnecchia and Kothmann (1982).
} 
(LIVE) or the sum of the standing live and dead components (TOTAL). Total ANPP for both methods was calculated by summing across species.

All standing crop data were subjected to least squares analyses of variance utilizing a split block model (Little and Hills 1978). Main effects were treatment (RG-14 vs. RG-42), time (before and after grazing), and category (live vs. dead). The error term for testing significant effects $(P<0.05)$ of treatment, time, and treatment by time interactions was pastures within treatment. The residual was used to test for significant $(P<0.05)$ category, category by treatment, category by time, and the 3-way interaction effects. A splitplot model was used to test for significant $(P<0.05)$ differences among years and between treatments in ANPP estimates (Little and Hills 1978). Student $Q$ tests were used for mean separations when appropriate (Snedcor and Cochran 1967). Unless otherwise noted, statistical significance is at $P<0.05$.

\section{Results}

\section{Precipitation}

Precipitation during the 4 years was highly variable (Fig. 1) and ranged from $699 \mathrm{~mm}$ in 1982 to $561 \mathrm{~mm}$ in 1984 . Adequate precipitation during spring and abundant precipitation during fall generally prevented extended periods of drought during all years except 1984 when a rather severe drought extended from early spring to fall. The 1984 drought was accompanied by above-average temperatures from April through August.

\section{Herbage Standing Crop}

Seasonal dynamics of the herbage standing crop were quite similar in both treatments (Fig. 3) and closely coupled to the

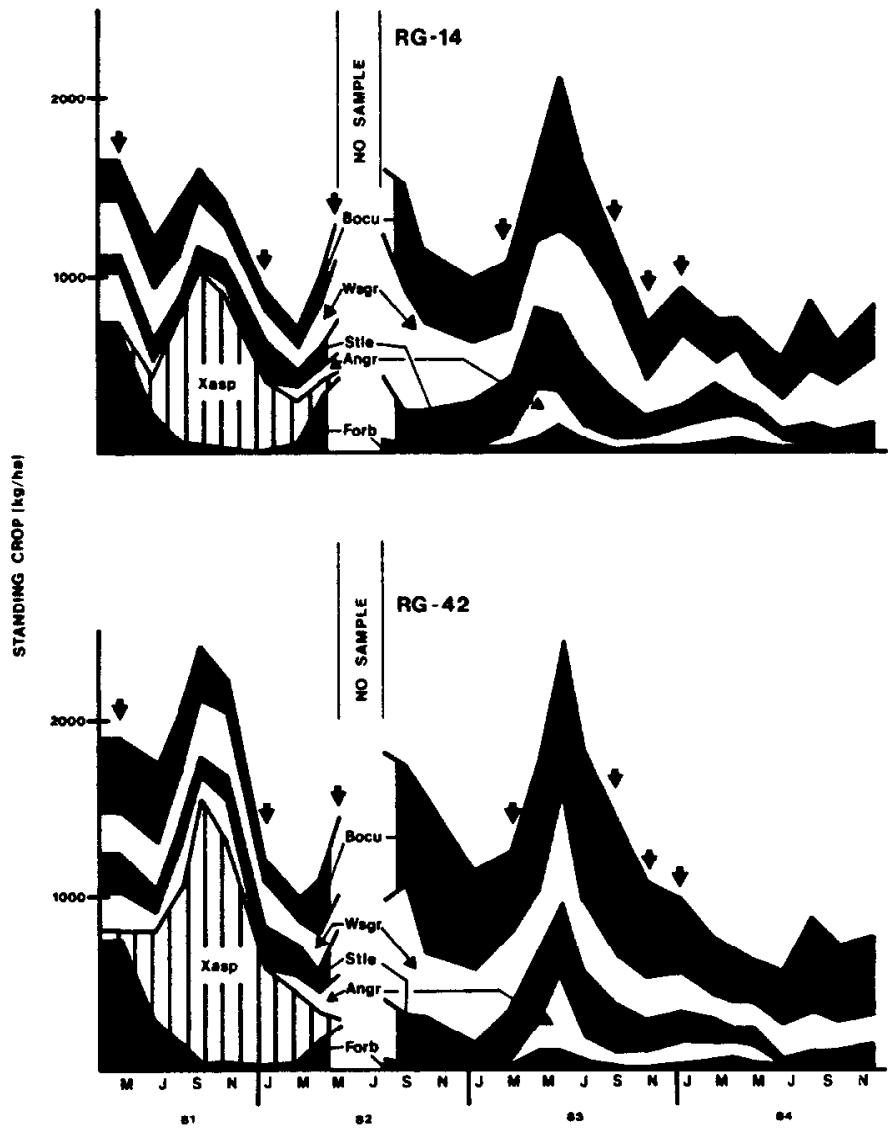

Fig. 3. Species and total herbaceous standing crop $(\mathrm{kg} / \mathrm{ha})$ for the $R \mathrm{G}-14$ and RG-42 treatments from May 1981 to December 1984. Each of the 26 data points depict the average standing crop before and after grazing. Arrows identify sample dates when total standing crop declined significantly $(\mathrm{P}<0.05)$ during grazing event. No sample = lost sample because of excessive rainfall event. See text (Methods) for species identification codes. interaction effects of temperature and precipitation (Fig. 1). Biomass generally began to accumulate in late winter and early spring as Stle, Angr, and Forbs began to grow (Figs. 4 and 5). The most rapid growth generally occurred in April, May, and June as the warm-season grasses (Bocu and Wsgr) began to grow. Peak standing crop generally occurred in early summer. Notable exceptions to
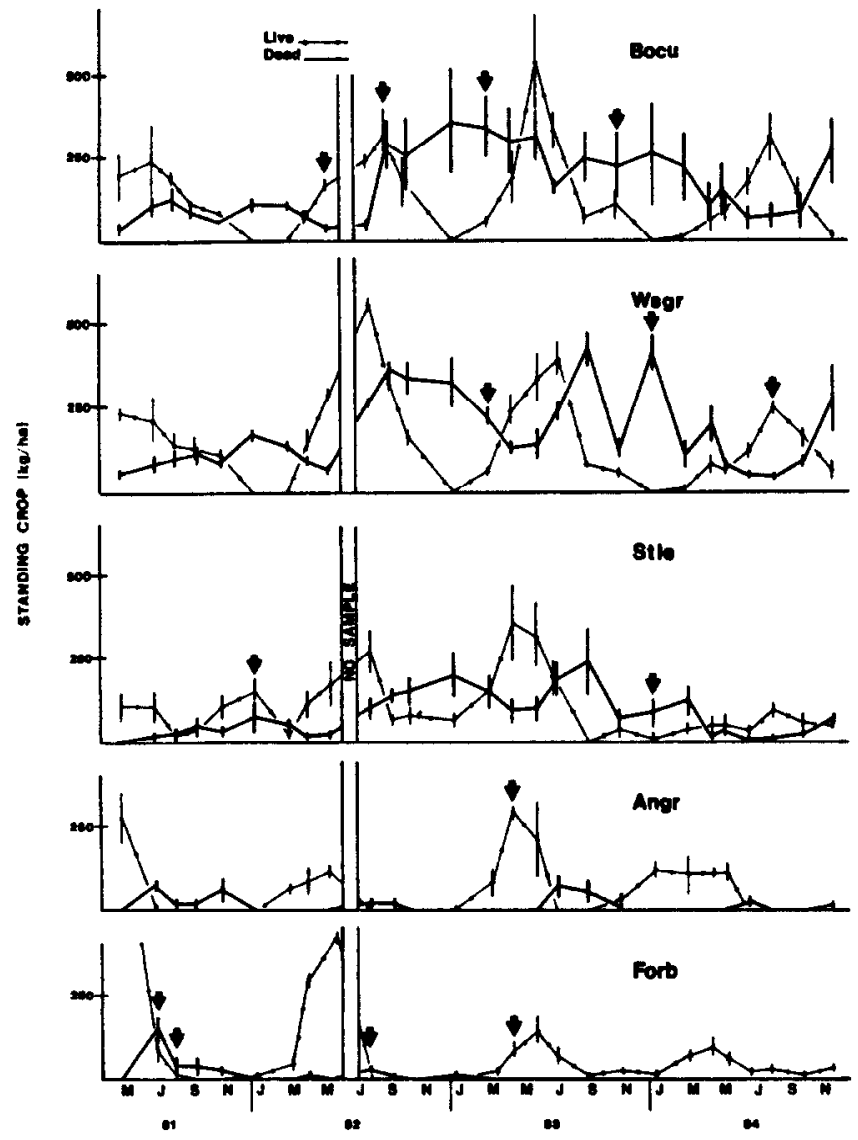

Fig. 4. Live and dead standing crops $(\mathrm{kg} / \mathrm{ha})$ for individual species in RG-14 treatment from May 1981 to December 1984. See Fig. 2 caption.

these generalizations were 1981 and 1984 . Peak standing crop in 1981 occurred in early fall because of the abundance of annual broomweed (Xasp), which matures vegetatively in early fall. Peak standing crop in 1984 was less than in 1981, 1982, and 1983, because of drought during the spring (Fig. 1). The resulting effect was that stocking rate was reduced in June 1984 from 3.7 ha/cow/ year to $5.2 \mathrm{ha} / \mathrm{cow} /$ year.

Statistical analyses of total standing crops indicated no major treatment effects although total standing crop in the RG-42 treatment was generally greater than in the RG-14 treatment (Fig. 3) both before (1981) and after subdividing the 31 -ha paddock. There were only 3 instances where standing crop of individual species (Figs. 4 and 5) varied significantly between treatments, which is fewer instances than that expected by chance alone (Table 1). In August 1982 and January 1984 there was a significantly greater amount of Wsgr in the RG-14 than RG-42 treatment while in August 1981 there was a significantly greater amount of Xasp in the RG-42 than RG-14 treatment.

Statistical analyses of the effect of individual grazing periods (time) on total standing crop indicated a significant decline occurred on 7 dates (Table 1, Fig. 3). Further examination showed only 2 instances where the total standing crop increased. On 3 dates there was a significant treatment by time interaction (Table 1). However, in all 3 instances the interaction was the result of differences between the 2 treatments in the relative amounts of decline.

Analyses of the effect of individual grazing periods on individual 

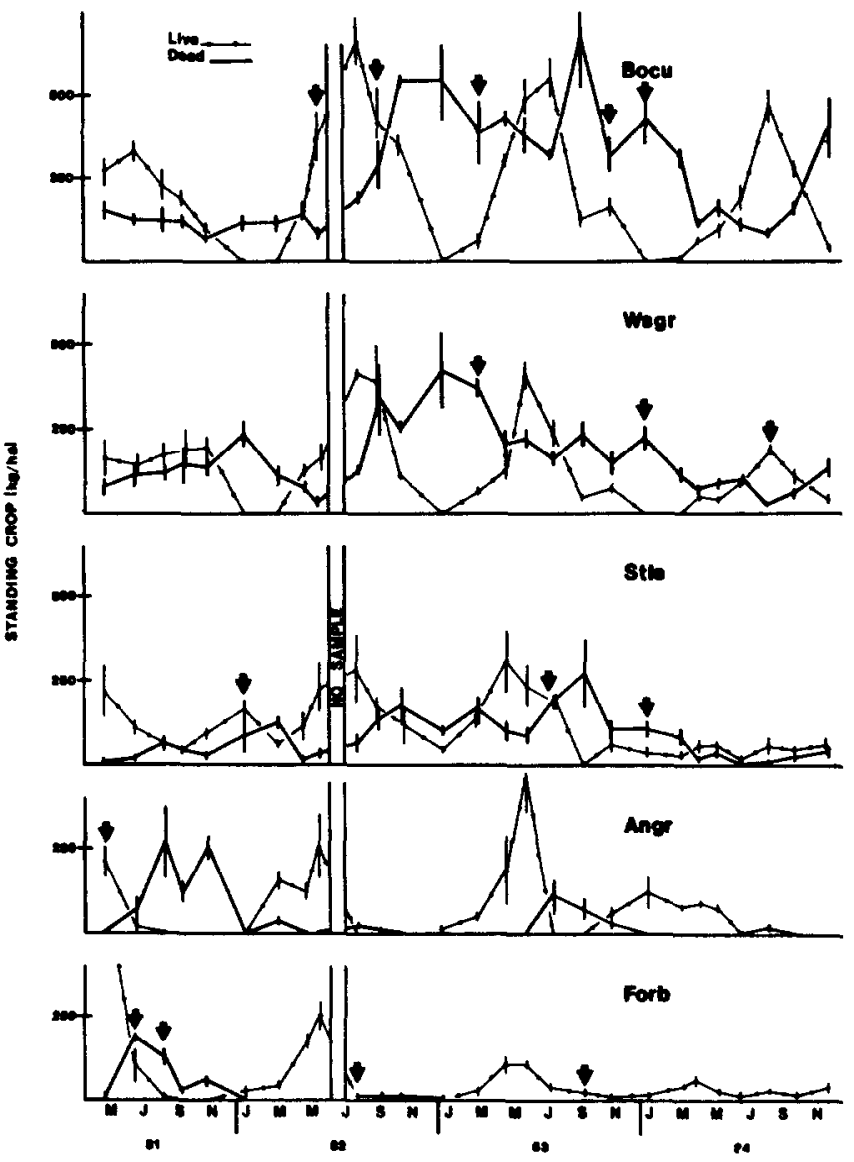

Fig. 5. Live and dead standing crops ( $\mathrm{kg} / \mathrm{ha}$ ) for individual species in RG-42 treatment from May 1981 to December 1984. See Fig. 2 caption.
Table 1. Sources of variation used in analysis of variance of herbage standing crop for 27 grazing periods and percentage of times mean squares were significant $(\boldsymbol{P}<0.05)$.

\begin{tabular}{|c|c|c|c|c|c|c|c|}
\hline \multirow[b]{2}{*}{ Source } & \multirow[b]{2}{*}{ Total } & \multicolumn{6}{|c|}{ Species } \\
\hline & & Angr & Stle & Bocu & Wsgr & Forb & Xasp ${ }^{3}$ \\
\hline Treatment $^{1}$ & 0 & 0 & 0 & 0 & 7 & 0 & 12 \\
\hline Time ${ }^{1}$ & 27 & 8 & 12 & 15 & 12 & 19 & 12 \\
\hline Trt. $\times$ Time & 4 & 8 & 4 & 4 & 4 & 15 & 25 \\
\hline Category ${ }^{2}$ & 93 & 33 & 74 & 100 & 89 & 74 & 100 \\
\hline Trt. $\times$ Cat. $^{2}$ & 15 & 11 & 15 & 11 & 15 & 15 & 25 \\
\hline Time $\times$ Cat. $^{2}$ & 12 & 0 & 8 & 4 & 8 & 8 & 0 \\
\hline 3-way² & 0 & 0 & 0 & 4 & 0 & 8 & 0 \\
\hline
\end{tabular}

1Error term $=$ pasture within treatment $(d . f=1)$

${ }^{2}$ Error term $=$ residual $(d . f .=4)$

${ }^{3}$ Only present during 8 grazing periods.

species showed few significant differences occurred between treatments in amounts of standing crop either before or after grazing (Table 1, Figs. 4 and 5). There was a significantly greater amount of Wsgr in the RG-14 quadrats $(820 \mathrm{~kg} / \mathrm{ha}$ ) than the RG-42 quadrats (541 kg/ha) in August 1982 and January $1984(412 \mathrm{vs.} 221 \mathrm{~kg} / \mathrm{ha})$ (Figs. 3, 4, and 5). There also was one date (June 1981) that standing crop of Xasp was significantly greater in the RG-42 quadrats (511 kg/ha) than the RG-14 (194 kg/ha)(Fig. 3, 4, and 5). As in the analyses of total standing crop, there were few significant treatment by time interaction effects (Table 1, Figs. 4 and 5) and no discernible treatment effects.

Differences in amounts of live and dead tissue varied significantly on most dates regardless of species (Table 1). Although in a few instances quantity of live and dead tissue varied significantly between treatments (treatment by category interaction effect), between before and after grazing (time by category interaction effect), and between treatments before and after grazing (3-way interaction effect), no definitive trends were apparent.

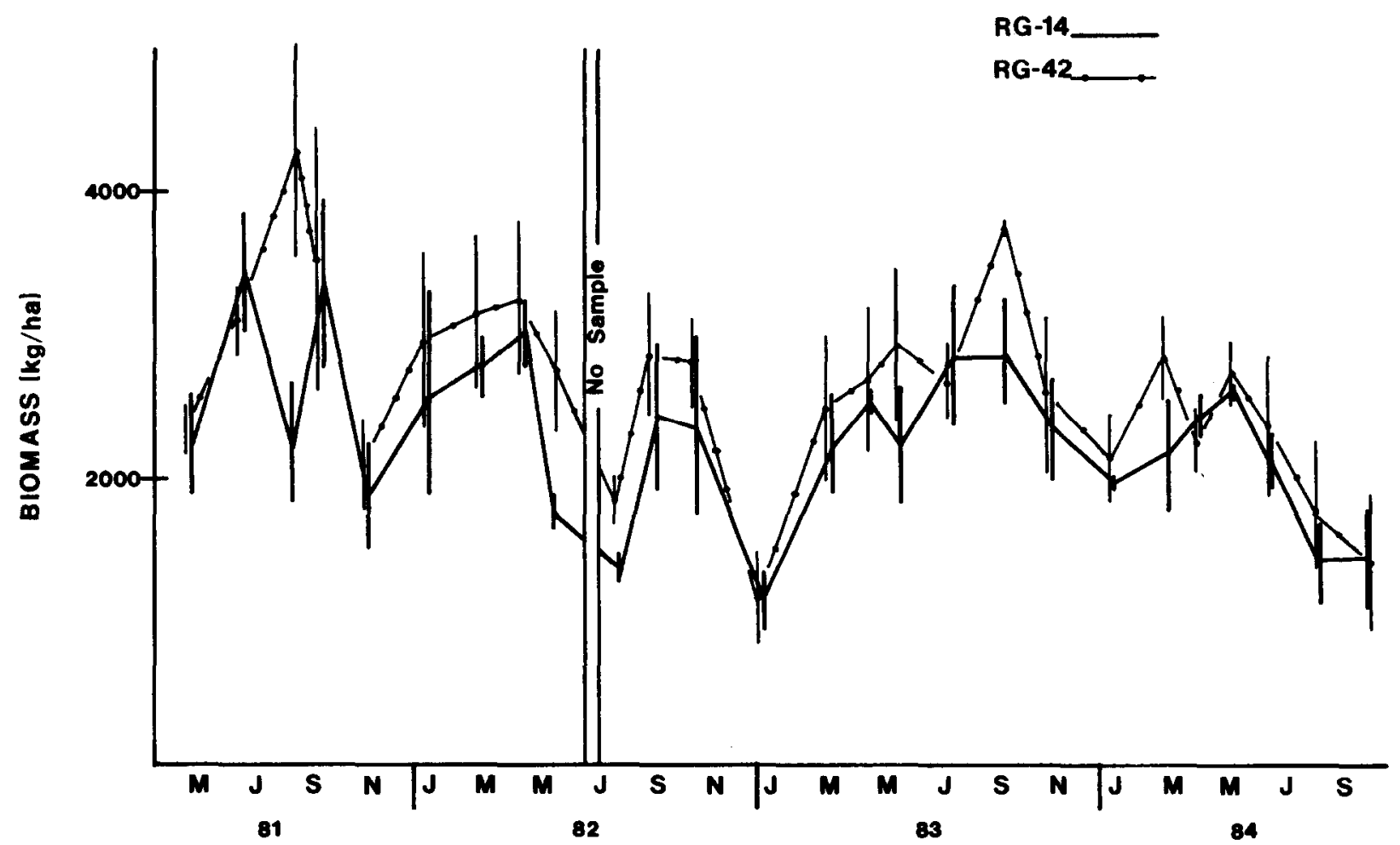

Fig. 6. Litter biomass $(\mathrm{kg} / \mathrm{ha})$ for the RG-14 and RG-42 teatments from May 1981 to December 1984. Each data point depicts the average of biomass before and after grazing. Vertical lines represent \pm 1 S.E.M. 


\section{Litter}

Statistical analyses of the litter data (Fig. 6) indicated no significant treatment or time effects and but one significant treatment by time interaction effect. The interaction effect occurred in August 1981 prior to subdividing the single RG-42 paddock into 3 paddocks. On this date, litter biomass in the RG-14 paddocks was significantly less both before $(2,897 \mathrm{~kg} / \mathrm{ha})$ and after $(1,633 \mathrm{~kg} / \mathrm{ha})$ grazing than in the $R G-42$ paddock $(4,061$ and $4,549 \mathrm{~kg} / \mathrm{ha}$, respectively). The decline in litter biomass in the RG-14 paddocks during the grazing period also was significant while the increase observed in the RG-42 paddock was not significant.

Although the litter estimates were highly variable, 2 trends were apparent. First, a positive relationship between herbage and litter standing crops was apparent in that there was generally more litter in the RG-42 than RG-14 padd ocks and the amount of litter tended to decline over the 4 years of study (Fig. 6). These same trends were apparent in terms of the herbaceous forage standing crop (Fig. 3). Seasonal relationships between the litter biomass and herbage standing crop were, however, less well defined in terms of annual maximums and minimums. Secondly, it was apparent that litter biomass usually increased during a grazing period as would be expected because of the accelerated transfer of herbage standing crop into the litter component by trampling from grazing animals. During the 26 grazing periods, litter biomass in the RG-14 and RG-42 treatments increased 65 and $62 \%$ of the time, respectively. Although these increases were not statistically significant at $P<0.05$ it is important to note that litter biomass increased in both treatments $42 \%$ of the time while decreasing in both treatments only $14 \%$ of the time.

\section{ANPP}

Total ANPP varied significantly among years but not among treatments $(P=0.49)$ when based on positive increases in the live component (LIVE) of individual species. Annual ANPP estimates ranged from $3,899 \mathrm{~kg} / \mathrm{ha}$ in 1981 to $1,187 \mathrm{~kg} / \mathrm{ha}$ in 1984 (Fig. 7).
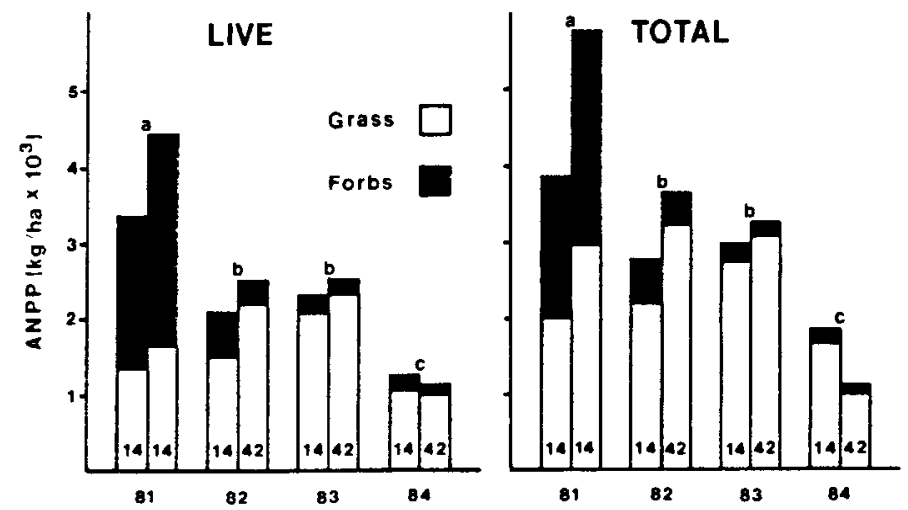

Fig. 7. Estimated ANPP ( $\mathrm{kg} / \mathrm{ha}$ ) forgrasses, forbs, and total in $R G-14$ and $R$ G-42 treatments for 1981 through 1984. See text (Methods) for description of 2 methods (Live and Total) used to calculate ANPP. ANPP estimates for individual years (average of $R G-14$ and $R G-42$ treatments) are significantly different $(\mathrm{P}<0.05)$ when superscripts located at top of bars are different. See text (Methods for species identification codes and for method.

Statistical analyses of the estimated ANPP of individual species showed several significant year effects, no significant treatment effects, and one significant year by treatment interaction effect. Mean separation procedures in this instance showed Bocu ANPP was significantly greater in the RG-42 paddocks $(828 \mathrm{~kg} / \mathrm{ha})$ than in the RG-14 paddocks ( $422 \mathrm{~kg} / \mathrm{ha}$ ) in 1982 (Fig. 8). There was no significant difference between treatments in Bocu production in 1983.

Total ANPP also varied significantly among years (Fig. 7) but not among treatments $(P=0.37)$ when based on changes in both the live and dead components (TOTAL). However, the treatment by
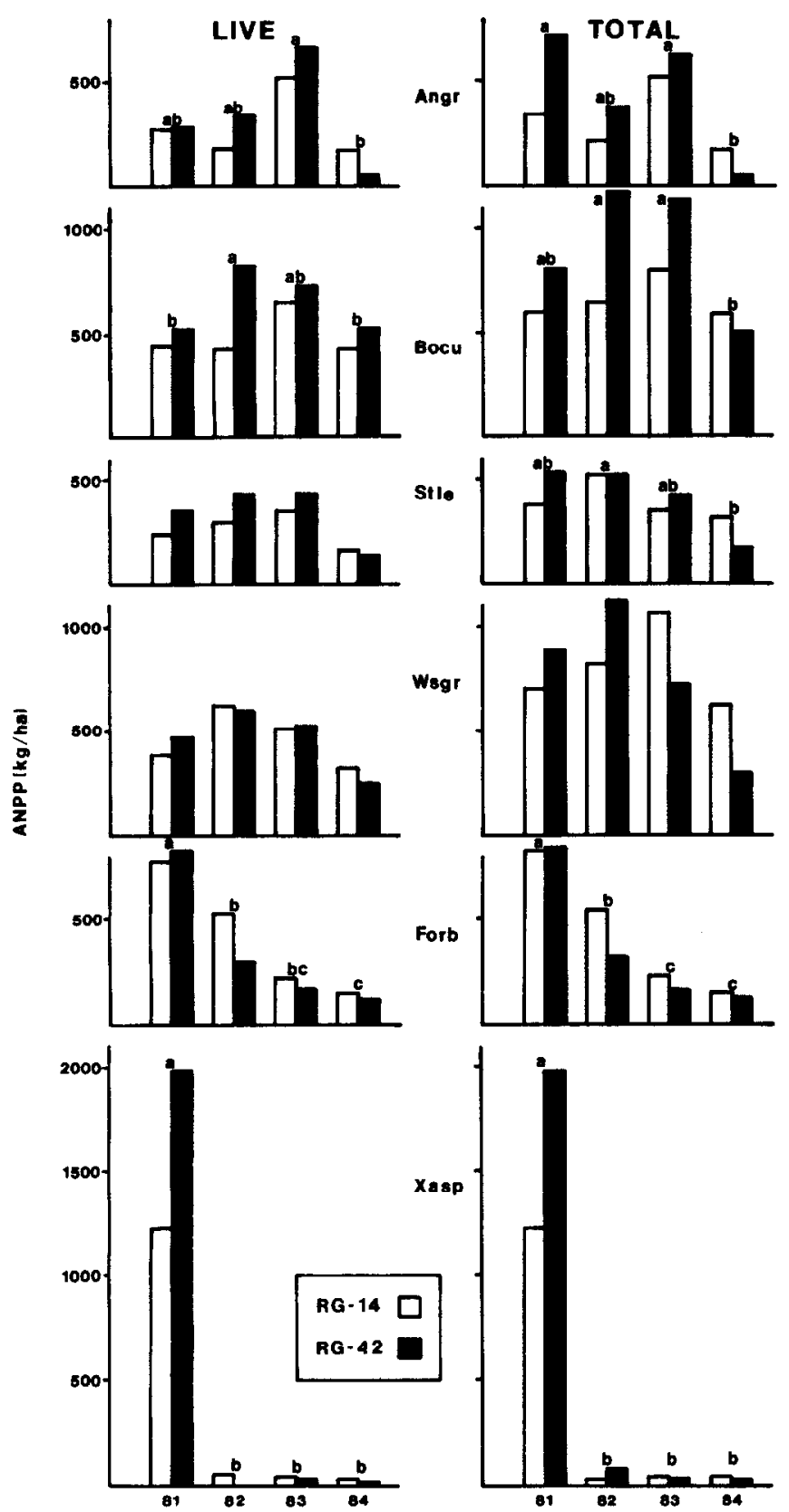

Fig. 8. Estimated ANPP ( $\mathrm{kg} / \mathrm{ha}$ ) for individual species in RG-14 and RG-42 treatments for 1981 through 1984. See Fig. 7 caption.

year interaction effect was significant in this analysis. Mean separation procedures showed total ANPP in the RG-42 paddocks was significantly greater than in the RG-14 paddocks in 1981 and 1982 because of the combined effect of nonsignificant differences between treatments in ANPP estimates for the individual species (Fig. 8). Statistical analyses of estimates by individual species revealed several significant year effects, no significant treatment effects, and one significant year by treatment interaction effect. Mean separation procedures for the single significant year by treatment interaction effect showed ANPP of Bocu was significantly greater in the RG-42 treatment in both 1982 and 1983 than in the RG-14 treatment.

Total grass production (Angr + Stle + Bocu + Wsgr) also varied significantly among years depending on method of calculation, but not between treatments. Based on changes in the live component (LIVE), grass production was significantly greater in $1983(2,192$ $\mathrm{kg} / \mathrm{ha})$ than $1981(1,493 \mathrm{~kg} / \mathrm{ha})$ and $1984(1,038 \mathrm{~kg} / \mathrm{ha})$, and in 
1981 and $1982(1,864 \mathrm{~kg} / \mathrm{ha})$ than 1984 . There was no difference between 1981 and 1982 . Based on changes in both the live and dead components (TOTAL), estimated ANPP of grass was significantly less in $1984(1,342 \mathrm{~kg} / \mathrm{ha})$ than $1981(2,488 \mathrm{~kg} / \mathrm{ha}), 1982(2,703$ $\mathrm{kg} / \mathrm{ha})$, and $1983(2,896 \mathrm{~kg} / \mathrm{ha})$. The year by treatment interaction effects were not significant in either analysis.

It should be noted that estimates of total ANPP in this study were quite similar to previous estimates at the ranch for a similar site located within a 10-paddock RG treatment (Heitschmidt et al. 1982b). Estimated ANPP's in that study were $3,300 \mathrm{~kg} /$ ha in 1978 and $2,680 \mathrm{~kg} / \mathrm{ha}$ in 1979 .

Table 2. Estimated harvest efficiencies.

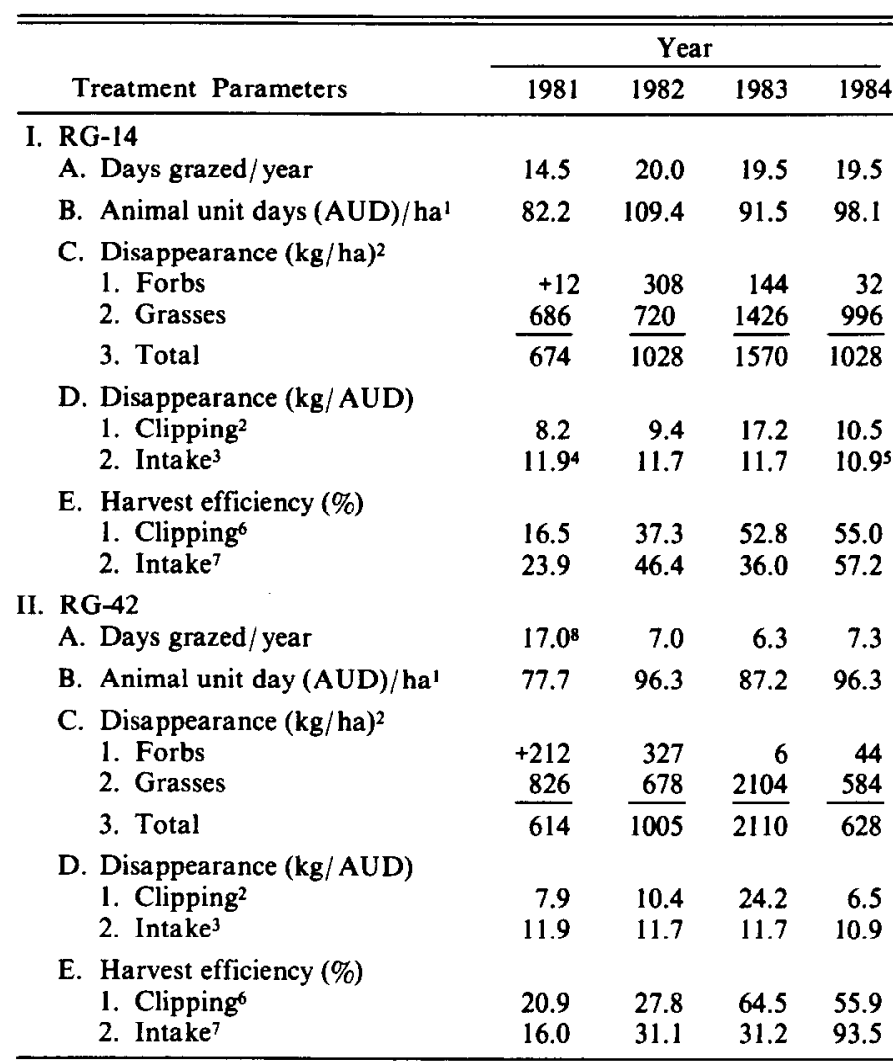

Idjusted for seasonal differences in herd structure relative to size (weight), physiolog ical status, and number of cows, calves, bulls, and diet steers (unpublished records). Animal-unit is I mature (454 kg) cow (SRM 1974). Animal-unit conversion factors used in calculations were based on NRC (1984) estimates.

${ }^{2}$ Based on difference in herbage standing crop before and after grazing.

${ }^{3}$ Based on dry matter intake/AUD of $11.8 \mathrm{~kg}$ (SRM 1974).

${ }_{4}^{4}$ April through December.

SJanuary through October.

$6[$ Disappearance (C.3.)/Total ANPP (Fig. 5)] $\times 100$.

' $\{$ (AUD/ha(B.) $\times$ Intake (D.2)]/Total ANPP (Fig. 5) $\} \times 100$.

${ }^{8}$ Total days grazed in 30-ha paddock prior to subdivision in March 1982.

\section{Harvest Efficiency}

Estimated harvest efficiencies (Table 2) indicated minimal treatment effects following subdivision in March 1981 regardless of method of calculation. Based on clipping, harvest efficiency during 1982,1983 , and 1984 averaged $48 \%$ and $49 \%$, respectively, in the RG-14 and RG-42 paddocks. Estimates based on calculated intakes during these 3 years averaged $47 \%$ and $52 \%$, respectively. The lack of a major difference between treatments in harvest efficiency estimates was not unexpected because stocking rates in both treatments were essentially equal.

Differences among years were of considerably greater magnitude than differences between treatments. This was primarily because of differences among years in total ANPP and relative composition. For example, estimated efficiencies during 1981 were well below the average for the 4 years while the 1984 estimates were well above average (Table 2). The lower estimate in 1981 resulted from the abundant production of forbs particularly annual broomweed (Fig. 8), which are not normally a major component of cattle diets in this region (Anderson 1977, Allison and Kothmann 1979 , de Moraes 1985). When forbs were excluded in the calculated efficiency estimates for 1981, the estimated efficiencies, based on intake, increased in the RG-14 paddocks from $24 \%$ to $34 \%$ and from $16 \%$ to $25 \%$ in the $\mathbf{R G}-\mathbf{- 4 2}$ treatment. The greater harvest efficiencies in 1984 were a result of lower ANPP estimates which were less in 1984 than the 3 other years particularly in the RG-42 paddocks.

When harvest efficiencies were calculated for individual grazing periods, based on changes in standing crop, and for individual species, based on annual ANPP estimates, considerable variation was encountered. This variation was not unexpected because our study areas were small, relative to the total size of each paddock, and they were located within a single plant community/range site. Concurrent research in these paddocks showed species composition of diets varied among dates (de Moraes 1985) as did distribution of grazing time among plant communities/range sites (unpublished data). Thus, it can be assumed that grazing intensity during any given grazing period varied considerably among the 4 study areas as well as among plant species. However, the lack of major differences between treatments in annual harvest efficiency estimates shows that levels of grazing intensity on the 4 study sites were probably equivalent when averaged across grazing periods for an entire year. This suggests grazing preference for our study sites was not significantly affected by stocking density.

It also should be noted that harvest efficiencies in this study, based on forage disappearance, are quite similar to previous estimates at the ranch in a 10-paddock RG treatment (Heitschmidt et al. 1982b). Total disappearance in that study was $1,210 \mathrm{~kg} / \mathrm{ha}$ in 1978 and $1,230 \mathrm{~kg} /$ ha in 1979 with subsequent harvest efficiency estimates of $36 \%$ and $46 \%$ for 1978 and 1979 , respectively. However, the estimates of harvest efficiencies based on estimated intake vary drastically between this study and the earlier study. The reason for this disparity is that the 1978-1979 estimates of intake were incorrect due to a miscalculation. Reexamination of the 1978-1979 data showed estimated intake was $1,400 \mathrm{~kg} / \mathrm{ha}$ not 140 $\mathrm{kg}$ as originally reported. Thus, the conclusion presented in the previous paper that most herbage "losses were either directly to the litter compartment or to other consumers" was incorrect. The revised estimates of harvest efficiency, based on estimated intakes, are $42 \%$ and $52 \%$ for 1978 and 1979 , respectively. Combining the data from 1978-1979 study and this study (Table 2) suggests that although calculated harvest efficiencies vary considerably among years and between methods of calculation, average efficiency in heavily stocked RG treatments appears to be near $40 \%$. Utilizing the 8 estimates from this study (Table 2), and the 2 revised estimates from the previous study (Heitschmidt et al. 1982b), average efficiency based on clipping data was $41 \%$ while average efficiency based on estimated intakes was $43 \%$.

\section{Discussion}

The decision to utilize the 14-paddock design at the onset of this study was influenced primarily by our desire to use existing line fences where possible and the observations of laymen at other locations. Of particular influence were the purported claims of laymen relative to the vegetation and livestock response at the Liebigs Ranch in Zimbabwe, following establishment of a 30paddock grazing cell (Savory and Parsons 1980), as well as the general positive observations of Howell (1978) in South Africa and Goodloe (1969) in Zimbabwe relative to the effects of RG treatments on herbage production. There also was some scientific evidence at the time that showed vegetation response was quite similar under continuous grazing and rotational grazing with few paddocks (3-9) (Morely et al. 1969, Gammon and Roberts 1978, Gammon 1978) but that increased productivity could theoretically be expected by increasing number of paddocks (Noy-Meir 1976). 
The results of this study, however, do not support a hypothesis that forage production in a RG treatment will vary as a function of livestock density as affected by number of paddocks. This is evidenced in this study by the general absence of statistically significant treatment, treatment by time, treatment by category, and treatment by time by category effects (Table 1). This conclusion must be qualified, however, because although we increased livestock density 3-fold during the study, the number of paddocks prior to subdivision was generally greater than the number of paddocks in most previous studies. Still, these results are in general agreement with the results of other quantitative studies that examined the effects of number of paddocks in a RG treatment on various vegetation parameters. Tainton et al. (1977) investigated the effects of different combinations of graze/rest periods on Moist Tall Grassveld in Natal. Their 9 treatments consisted of 2, 10, and 20-day graze periods in all combinations with 20,40 , and 60 -day rest periods. Grazing pressure was held constant across treatments. They concluded from this 8-year study that although differences among treatments in vegetation response were small, the response in 2 treatments was slightly superior. These 2 treatments were 2-day graze/60-day rest and 10-day graze/60-day rest. They concluded that because the former treatment would require 31 paddocks to implement and the later only 7, the latter was far more practical for ranchers to implement than the former treatment. Likewise, Denny et al. (1977), Denny and Barnes (1977), and Denny and Steyn (1977) examined the effect of various combinations of paddock numbers $(4,8,12$, and 16$)$, stocking rates (2), and lengths of grazing periods $(5,10$, and 20 days) on veld vegetation in Zimbabwe. They also concluded from their 6-year study that there was minimal difference among treatments in the response of the vegetation in terms of their effects on botanical composition and density of perennial grass plants. Results from both these studies tended to support the earlier conclusions of Morely (1968) and Booysen et al. (1974). Both concluded that if the objectives of RG systems are to avoid grazing regrowth during any given grazing event and to allow sufficient rest between grazing events for adequate regrowth, then these can be adequately met in 8 to 9-paddock systems.

Since the beginning of our study no quantitative studies have been published that would support a conclusion contrary to our conclusion. Furthermore, it is interesting to note that scientific re-evaluations of the vegetation response in several rotational grazing treatments in Zimbabwe, including the Liebigs Ranch, have recently been completed (Gammon 1984). Paired comparisons were made between veld under intensive RG systems with large number of paddocks ( 14 to 42 ) and adjacent similar veld that had been less intensively managed. Because of the significance of these evaluations relative to the results of this and other studies, we quote:

"...In these comparisons the areas under intensive SDG were not markedly or consistently superior to adjacent less intensively managed areas in terms of basal cover, litter cover and species composition. These findings are in accord with those of Clatworthy (1975).

It is possible that these early reports of veld improvement on farms under SDG were inaccurate, being based on visual impressions with no recorded measurements to monitor change. Alternatively, improvement may have occurred, but at a similar rate to that in less intensively managed veld. The latter possibility seems most likely in the case of reports of veld improvement during the relatively high rainfall period of the 1970s (Swift, 1979). Spectacular improvement in veld condition is reported to have occurred on Liebigs Ranch, under a 32 paddock SDG system in a cartwheel layout. This was applied in 1972 to an area with a mean annual rainfall of 360 $\mathrm{mm}$ in veld which was in very poor condition throughout the area. That marked improvement took place there is no doubt, but it is important to note that during the first nine years of application the rainfall averaged approximately 50 per cent above the mean. Comparisons of veld condition showed that the surrounding less inten- sively managed veld was in similar condition and must have shown similar improvement.

Generally intensive SDG was applied at higher stocking rates than had normally been recommended, and such stocking rates appeared to be sustainable through the 1970 s. While it is reasonable to suppose that some degree of increased carrying capacity can be achieved with intensive management, it is not known to what extent this increased carrying capacity was attributable to the period of increased rainfall that accompanied the introduction of SDG. Probably the greatest increase in stocking rate was applied on Liebigs Ranch in the 32 paddock system. Here a stocking rate more than 100 per cent heavier than normal recommendations was applied successfully, with good animal performance for a period of eight years of above average rainfall (1972 to 1980). However, in the following two seasons (1980/81 and 81/82) of approximately average rainfall, progressive reductions in stocking rate had to be made, bringing the rate to approximately 50 per cent above normal recommendations. At this level, the paddocks became critically short of grass by November, 1982, at which time the system was completely destocked. The area was thus destocked before the effects of the 1982/83 drought was felt and has carried no stock through this drought. It is clear that in years of high rainfall stocking rates at least double the normal recommendations could be sustained under this system. It is not possible to assess accurately what stocking rate could be sustained in average or slightly below average seasons. However, in this case a level 50 percent higher than normal was too heavy in such circumstances."

Finally it may seem that the results of this and most other quantitative studies are in direct conflict with the basic underlying biological theory of RG (Voisen 1959; Acocks 1966; Booysen and Tainton 1978; Gammon 1978, 1984; and Heitschmidt et al. 1982a) as incorporated into such mathematical simulation models as those presented by Noy-Meir (1976) and Senft and Malechek (1985). The analytical simulation model presented by Noy-Meir suggested that when stocking rates were high, as in our study, intensive rotation (many subdivisions and/or long rests) increased long-term productivity as compared to continuous grazing. Likewise, the model by Senft and Malechek suggested weight gain/ha for steers grazing crested wheatgrass [Agropyron cristatum (L). Gaertn.]-dominated grasslands would be greatest when length of graze was low (1 day), number of paddocks was high (30), and stocking rate was high. An explicit assumption in both models was, however, that the relative growth rate of the entire vegetation complex is constant throughout the grazing season. Obviously, this assumption is unrealistic for arid and semiarid rangelands that support a heterogeneous mixture of forage species. In fact, the only conceptual model that strongly emphasizes the merits of RG during adverse vegetation growth periods is that which includes the concept of positive effect of physical animal impacts (Savory and Parsons (1980). The scientific credibility of this model must be questioned, however, in light of the results of this study as well as those from several other recent studies. For example, Balph and Malechek (1985) have shown in Utah that cattle tend to avoid stepping on tussocks of grass thereby increasing trampling of the barren, interstitual soil surfaces. This in turn destroys the cryptogamic crusts found on these areas, which tends to reduce the chances for successful establishment of seedlings (St. Clair et al. 1984) and to decrease water infiltration rates and increase soil erosion (Loope and Gifford 1972) in this region. Likewise, recent studies in Texas have shown that $R G$ at high rates of stocking tends to decrease water infiltration rates and increase sediment production (Pluhar et al. 1987, Warren et al. 1986a, Warren et al. 1986b) and increase density of cattle trails (Walker and Heitschmidt 1986). The results from these various studies simply emphasize that caution should be exercised by management personnel utilizing grazing management strategies that are biologically justified by the assumption that the physical impact of herbivores on structure and function of grassland ecosystems is always positive. 


\section{Literature Cited}

Acocks, J.P.H. 1966. Non-selective grazing as a means of veld reclamation. Proc. Grassland Soc. S. Afr. 1:33-39.

Allison, C.D., and M.M. Kothmann. 1979. Effect of level of stocking pressure on forage intake and diet quality of range cattle. Proc. West. Sec. Amer. Soc. Anim. Sci. 30:174-178.

Anderson, D.M. 1977. Standing crop, diets, travel and weight changes under short-duration and continuous grazing. $\mathrm{Ph}$. $\mathrm{D}$. Diss. Texas A\&M Univ., College Station.

Balph, D.F., and Malecheck, J.C. 1985. Cattle trampling of crested wheatgrass under short-duration grazing. J. Range Manage. 38:226-227.

Booysen, P. De V., J.R. Klug, and B.S. York. 1974. Number of camps for rotational grazing of veld. Proc. Grassl. Soc. S. Afr. 9:145-148.

Booysen, P. De V., and N.M. Tainton. 1978. Grassland management: Principles and practices in South Africa, p. 551-554. In: D.N. Hyder (ed.), Proc. Ist Internat. Range. Congr., Soc. Range Manage., Denver, Colo.

Clatworthy, J.N. 1975. Results of the botanical analyses in the Charter trial. Rhodesian Branch S. Afr. Soc. Anim. Prod. mimeo.

Denny, R.P., and D.L. Bames. 1977. Trials of multi-paddock grazing systems on veld. 3 . A comparison of 6 grazing procedures at 2 stocking rates. Rhodesia J. Agr. Res. 15:129-142.

Denny, R.P., D.L. Barnes, and T.C.D. Kennan. 1977. Trials of multippaddock grazing systems on veld. 1. An exploratory trial of systems involving 12 paddocks and 1 herd. Rhodesia J. Agr. Res. 15:11-23.

Denny, R.P., and J.S.H. Steyn. 1977. Trials of multi-paddock grazing systems on veld. 2 . A comparison of a 16 paddocks-to-one-herd system with a 4 paddocks-to-one-herd system using breeding cows. Rhodesia $J$. Agr. Res. 15:119-127.

Gammon, D.M. 1978. A review of experiments comparing systems of grazing management on natural pastures. Proc. Grassland Soc. S. Afr. 13:75-82.

Gammon, D.M. 1984. An appraisal of short duration grazing as a method of veld management. Zimbabwe J. Agr. Res. 84:59-64.

Gammon, D.M., and B.R. Roberts. 1978. Characteristics of herbage on offer during continuous and rotational grazing of the Matopos sandveld of Rhodesia. Rhod. J. Agr. Res. 16:3-22.

Goodloe, S. 1969. Short duration grazing in Rhodesia. J. Range Manage. 22:369-373.

Heitschmidt, R.K., S.L. Dowhower, R.A. Gordon, and D.L. Price. 1985. Response of vegetation to livestock grazing at the Texas Experimental Ranch. Texas Agr. Exp. Sta. B-1515.

Heitschmidt, R.K., J.R. Frasure, D.L. Price, and L.R. Rittenhouse. 1982a. Short duration grazing at the Texas Experimental Ranch: Weight gain of growing heifers. J. Range Manage. 35:375-379.

Heitschmidt, R.K., D.L. Price, R.A. Gordon, and J.R. Frasure. 1982 b. Short duration grazing at the Texas Experimental Ranch: Effects on aboveground net primary production and seasonal growth. J. Range Manage. 35:367-372.
Howell, L.N. 1978. Development of multi-camp grazing systems in the Southern Orange Free State, Republic of South Africa. J. Range Manage. 31:459-465.

Little, T.M., and F.J. Hills. 1978. Agricultural experimentation: Design and analysis. John Wiley and Sons, New York.

Loope, W.L., and G.F. Gifford. 1972. Influence of a soil microfloral crust on select properties of soils under pinyon-juniper in southeastern Utah. J. Soil and Water Conserv. 27:164-167.

Moraes, E.A., de. 1985. Cattle diets from yearlong and rotational grazing at two stocking densities on the Texas Experimental ranch. Ph.D. Thesis, Texas A\&M Univ., College Station.

Morley, F.H.W. 1968. Pasture growth curves and grazing management. Aust. J. Exp. Agr. and Anim. Husb. 8:40-45.

Morley, R.H.W., D. Bennett, and G.T. McKinney. 1969. The effect of intensity of rotational grazing with breeding ewes on phalaris-subterranean clover pastures. Aust. J. Exp. Agr. and Anim. Husb. 9:74-84.

National Research Council. 1984. Nutrient requirements of beef cattle. Nat. Acad. Press, Washington, D.C.

Noy-Meir, I. 1976. Rotational grazing in a continuously growing pasture: A simple model. Agr. Sys. 1:87-112.

Pluhar, J.J., R.W. Knight, and R.K. Heitschmidt. 1987. Infiltration rates and sediment production as influenced by grazing systems in the Texas Rolling Plains. J. Range Manage. (In press)

Savory, A., and S.D. Parsons. 1980. The Savory grazing method. Rangelands 2:234-237.

Scarnecchia, D.L., and M.M. Kothmann. 1982. A dynamic approach to grazing management terminology. J. Range Manage. 35:262-264.

Senft, R.L., and J.C. Malechek. 1985. Short duration grazing cell parameters and cattle production: A low-resolution model. Proc. West. Sec. Amer. Soc. Anim. Sci. 36:282-285.

Snedecor, G.W., and W.C. Cochran. 1967. Statistical methods. 6th ed. Iowa St. Univ. Press, Ames.

Society Range Management. 1974. A glossary of terms used in range management. Soc. Range Manage, Denver, Colo.

St. Clair, L.L., B.L. Webb, J.R. Johansen, and G.T. Nebeker. 1984. Cryptogamic soil crusts: Enhancement of seedling establishment in disturbed and undisturbed areas. Reclamation and Revegetation Res. 3:129-136.

Swift, R.D. 1979. Grazing management on Bemthree Ranch, Kwekwe. Symp. on Veld Manage., Grassl. Soc. S. Afr. Salisbury.

Tainton, N.M., P. de V. Booysen, and R.C. Nash. 1977. The grazing rotation. Effects of different combinations of presence and absence. Proc. Grassl. Soc. S. Afr. 12:103.

Voisin, A. 1959. Grass productivity. Philosophical Library Inc., New York.

Walker, J.W., and R.K. Heitschmidt. 1986. Effect of various grazing systems on type and density of cattle trails. J. Range Manage. (39:428-431).

Warren, S.D., W.H. Blackburn, and C.A. Taylor. 1986a. Soil hydrologic response to number of pastures and stocking density under intensive rotational grazing. J. Range Manage. 39:500-504.

Warren, S.D., T.L. Thurow, W.H. Blackburn, and N.E. Garza. 1986 b. Influence of livestock trampling under rotational grazing on soil hydrologic characteristics. J. Range Manage. 39:491-495 